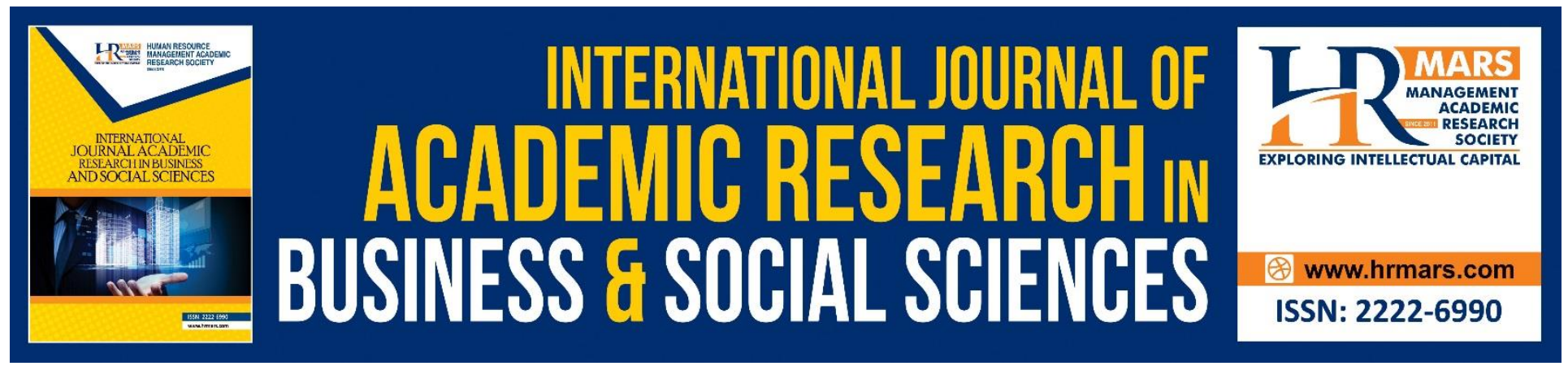

\title{
Functional Brand Attributes and the Corporate Brand Image of Islamic Banking Institutions
}

Siti Ngayesah Ab Hamid, Wan Jamaliah Wan Jusoh, Suharni Maulan

To Link this Article: http://dx.doi.org/10.6007/IJARBSS/v8-i12/5188

DOI: $10.6007 /$ IJARBSS/v8-i12/5188

Received: 14 Nov 2018, Revised: 23 Dec 2018, Accepted: 30 Dec 2018

Published Online: 12 Jan 2019

In-Text Citation: (Hamid, Jusoh, \& Maulan, 2018)

To Cite this Article: Hamid, S. N. A., Jusoh, W. J. W., \& Maulan, S. (2018). Functional Brand Attributes and the Corporate Brand Image of Islamic Banking Institutions. International Journal of Academic Research in Business and Social Sciences, 8(12), 2326-2334.

Copyright: (C) 2018 The Author(s)

Published by Human Resource Management Academic Research Society (www.hrmars.com)

This article is published under the Creative Commons Attribution (CC BY 4.0) license. Anyone may reproduce, distribute, translate and create derivative works of this article (for both commercial and non-commercial purposes), subject to full attribution to the original publication and authors. The full terms of this license may be seen

at: http://creativecommons.org/licences/by/4.0/legalcode

Vol. 8, No. 12, 2018, Pg. 2326 - 2334

http://hrmars.com/index.php/pages/detail/IJARBSS

JOURNAL HOMEPAGE

Full Terms \& Conditions of access and use can be found at http://hrmars.com/index.php/pages/detail/publication-ethics 


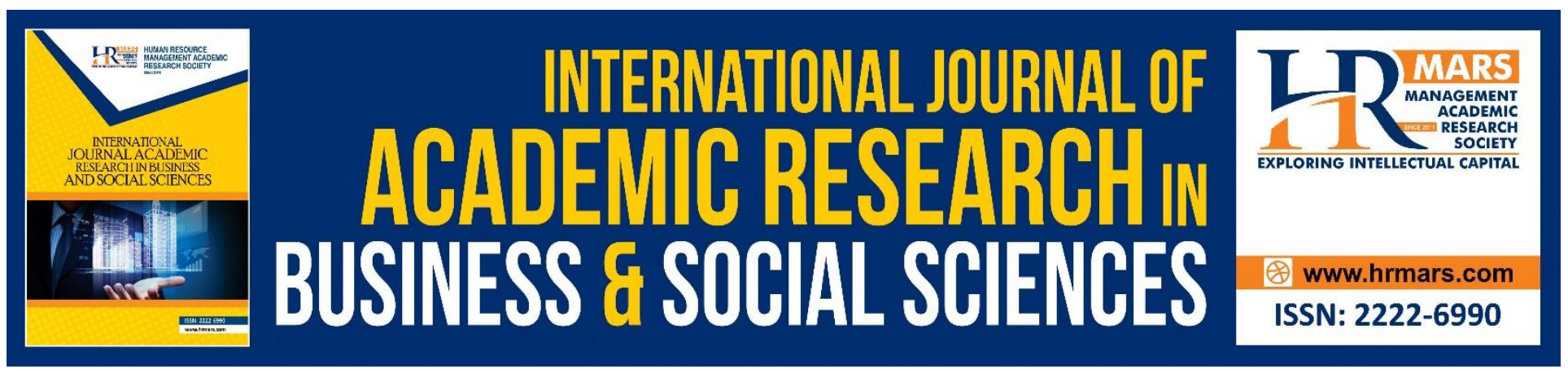

\title{
Functional Brand Attributes and the Corporate Brand Image of Islamic Banking Institutions
}

\author{
Siti Ngayesah Ab Hamid', Wan Jamaliah Wan Jusoh², Suharni \\ Maulan ${ }^{3}$ \\ ${ }^{1 *}$ Faculty of Economics and Management, Universiti Kebangsaan Malaysia, Bangi, Malaysia \\ 2,3Business Administration Department, International Islamic University Malaysia, Kuala Lumpur, \\ Malaysia
}

\begin{abstract}
Building a favourable corporate brand image is crucial in determining the long term success of businesses, especially in the service sector. Although various studies have been conducted on the image of conventional institution, limited studies could be found in trying to understand the image of an organisation incorporating Islamic values. Therefore, this study aims to review the factors influencing the corporate brand image of Islamic banking institutions, which are the functional brand attributes. Details on the functional brand attributes of Islamic banking institutions, which is measured by contact personnel, access to service and product offerings and its relationship with the overall corporate brand image, is provided. Based on the reviews of literature, a model depicting the relationship between the construct is proposed, and hypothesis is developed.
\end{abstract}

Keywords: Brand Attribute, Functional Brand Attribute, Corporate Brand Image, Brand Image, Islamic Bank

\section{Introduction}

The Islamic banking sector has grown tremendously not only in Malaysia, but also in other parts of the world. As a dominant segment in the Islamic Financial Services Industry, the amount of assets for the Islamic banking sector worldwide has reached USD1.5 trillion as in the first half of the year 2015 (IFSB, 2016) and in the Malaysian banking sector alone, the market share of Islamic banks has increased to $23 \%$ in the same period (IFSB, 2016). Despite this encouraging success, Islamic banks face an intense competition due to the increasing number of institutions established in the Islamic and conventional segments and the blurring differentiation in the products and services offered (Devlin, Ennew, \& Mirza, 1995). Not only that, studies also show that consumers are not aware of the differences between the Islamic and conventional banking concepts (Al-Tamimi et al., 2009; Islam \& Rahman, 2017). These unsuccessful differentiation attempts lead to various misconceptions (Ahmad, 2007), which among others, Islamic banks have been accused of being interest-based rather than 
interest-free, proving its depiction of their conventional rivals (Chong \& Liu, 2009) and the element distinguishing the Islamic bank from its conventional counterparts is only on the use of Islamic terminology, while the Shari'ah compliance aspect remains in question (Khan, 2010). These misleading beliefs and accusations signal an ineffective image differentiation effort and if remain unchanged may provide no reasons for customers to choose an Islamic brand over another (Ahmad et al., 2011), thus this matter needs to be handled carefully.

Therefore, in order to face these challenges, the Islamic banking institution is proposed to focus on branding efforts by developing a strong corporate brand image (Ahmad et al., 2011). Although studies on corporate image have enormously been done before, most of the studies focused on the large conventional corporation, while religiously oriented institutions are being neglected (Arpan, Raney, \& Zivnuska, 2003; Fetscherin \& Usunier, 2012). In the context of the Islamic bank, although some studies are available, majority of it focused on the emotional aspect of image only (e.g.: Osman, Syed Alwi, et al., 2015; Osman, Ali, Mokhtar, Setapa, \& Abd Malek, 2016), while the functional aspect is less covered, although it is widely accepted that image consists of two components, which are functional and emotional.

Hence, based on these arguments, this study attempts to focus on the influence of Islamic bank functional brand attributes towards the overall corporate brand image of the bank. By implementing this, hopefully the Islamic banking management would find a proper basis and guideline to form a suitable image for the bank.

\section{Literature Review \\ Functional Brand Attributes}

The functional brand attributes of a service refers to the tangible items of the brand that give an impact on service performance and could be easily evaluated such as price, accessibility, and reliability of service (Aranda, Gómez, \& Molina, 2015; Dowling, 1986; Kennedy, 1977; Martineau, 1958). These attributes solve consumption-related issues (Park, Jaworski, \& Maclnnis, 1986) and are able to fulfil the rational and practical needs (Bhat \& Reddy, 1998). Functional attributes may also relate to the perceived service quality (Da Silva \& Syed Alwi, 2008) and be interpreted as beliefs and knowledge on the brand physical attributes (Hosany, Ekinci, \& Uysal, 2006), as well as a cognitive attitude towards a brand (Syed Alwi \& Kitchen, 2014).

Various attributes have been found and categorised under the functional brand attributes of financial institutions, especially in the conventional context. Among others, variables related to the service and product offerings, accessibility, contact personnel and servicescape have been recognised as the most cited factors in the literature (Bravo et al., 2010; Durna, Dedeoglu, \& Balikçioglu, 2015; Nguyen \& Leblanc, 2002). Service offerings in the context of bank may be perceived from the angle of interest rate, innovation and variety of products (Bravo et al., 2010). However, in the context of Islamic bank, financial services offered should be guided by the divine revelation or shari'ah (Maulan, Omar, \& Ahmad, 2016; Temporal, 2011). On the other hand, accessibility refers to the convenience factor and the degree of easiness to use the service (Ahmad et al., 2011; Bravo et al., 2010), while servicescape relates to the style and attractiveness of the place in which service production and 
consumption is delivered (Bravo et al., 2010; Nguyen \& Leblanc, 2002). This includes the ambience and condition of the physical environment such as colour, odour, light and layout, which may facilitate the process of delivery and create comfortable atmosphere (Nguyen \& Leblanc, 2002). Lastly, contact personnel refers to the front-line employees who interact directly with clients and create a first impression towards the organisation (Nguyen \& Leblanc, 2002) through their manners in delivering service such as kindness and professionalism (Bravo et al., 2010; O'Cass \& Grace, 2003). Every interaction between the firm personnel and the customers plays a central role in the formation of a company's image (Anisimova, 2014; Jalilvand \& Samiei, 2012; Kennedy, 1977). For the Islamic bank, Muslim consumers perceive the bank to convey an Islamic brand identity if the bank personnel appears according to the Islamic dress code, for example by wearing hijab for women (Ashraf et al., 2015). Not only that, bank personnel should also understand and convey information on the sharia compliance aspect of products to customers (Awan \& Bukhari, 2011).

In the context of the Islamic bank, although studies evaluating the functional brand attributes and its influence towards image are scarce, Ahmad et al. (2011) so far has found the importance of contact personnel, accessibility, products and services offerings in influencing Islamic banking preference. Thus, based on this and the banking literatures in the conventional context, the study believes that contact personnel, access to service and product offerings are suitable to represent functional brand attributes. The conventional financial service studies have also found the relevancy of these three factors in determining corporate brand image (Leblanc \& Nguyen, 1996).

\section{Corporate Brand Image}

A human mind processes things based on its image and not exclusively based on the things itself. This process is called mental imagery, which involves input from sight, taste, sound, smell or multiple senses experience (Stern, Zinkhan, \& Jaju, 2001). The concept of image combined the perception of various objects or components to form an overall perception towards an organisation or brand (Haedrich, 1993). In the context of corporate brand, image has been defined by Gray and Balmer (1998) as "the mental picture of the company held by its audiences or what comes to mind when one sees or hears the corporate name or sees its logo". It has also been viewed to be based on "what people associate with the company or all the information (perceptions, inferences, and beliefs) about it that people hold" (Martenson, 2007).

Image has been argued to be an important aspect of a strong brand (Hosany et al., 2006) and plays an important role in the formation of brand equity (Aaker, 1991; Biel, 1993; Chen, Chen, \& Huang, 2012; Keller, 1993; Kim \& Hyun, 2011; Van Rekom et al., 2006). In a competitive business market, creating a powerful image is considered to be part of the positioning strategy (Aaker, 1991; Biel, 1993; DiMingo, 1987; Park et al., 1986; Van Rekom et al., 2006) to differentiate a company or its offering from competitors (Hsieh, Pan, \& Setono, 2004; Padgett \& Allen, 1997). In the case of intangible service, image is used by consumers to define a product in their mind and is proven to be able to influence selection and intention to purchase (Andreassen \& Lindestad, 1998; Dowling, 1986; Langrehr, 1985; Michel \& Rieunier, 2012). Not only that, studies also found that image plays an impact in influencing satisfaction (Andreassen \& Lindestad, 1998; Fatt, Wei, Yuen, \& Suan, 2000; Minkiewicz, Evans, Bridson, \& Mavondo, 2011; Palacio, Meneses, \& Pérez, 2002; Sallam, 2016) and loyalty (Andreassen \& Lindestad, 1998; Chung, Yu, Kim, \& Shin, 2016), as well as determining future 
behaviour (Andreassen \& Lindestad, 1998). This is especially important for the Islamic bank in which the services delivered is difficult to be evaluated, and customers is said to have a limited understanding and knowledge of the products offered.

As such, developing a strong corporate brand image should be a top priority of many organisations (O'Cass \& Grace, 2003), especially because it is considered as one of the intangible assets that cannot be copied by competitors (Sondoh Jr, Wan Omar, Abdul Wahid, Ismail, \& Harun, 2007; Yeo \& Youssef, 2010). Therefore, in order to develop a favourable image, understanding and determining the most valued attributes that form image is important so that corrective action can be taken and future strategies could be developed (Barich \& Kotler, 1991). Unfortunately, limited consensus exists on the measurement of image, and as such a sound research is needed (Winchester \& Fletcher, 2000). Understanding how image could be improved would help banking institutions to shape its operation and branding activities in a way that could boost image.

\section{Proposed Model}

Previous studies have shown the relationship between functional brand attributes and corporate brand image. In the context of business schools for example, cognitive brand attribute which is considered to be similar to functional brand attribute was found to be statistically significant in explaining corporate brand image (Syed Alwi \& Kitchen, 2014). Other than that, functional related attributes also were proven to be positively significant in influencing the corporate brand image in the context of online and offline retailing, although the attributes are different between the two contexts (Da Silva \& Syed Alwi, 2006). In destination image study, the functional brand attributes assessed through cognitive evaluation are said to have a stronger impact towards the image of the destination as compared to the affective evaluation (Martin \& Bosque, 2008). Hence, based on the result of the previous studies, in the context of the Islamic bank, the following hypothesis is proposed:

H1: There is a positive and significant relationship between functional brand attribute and the corporate brand image of Islamic banking institutions.

Figure 1.0 portrayed the model indicating the relationship between the two proposed constructs.

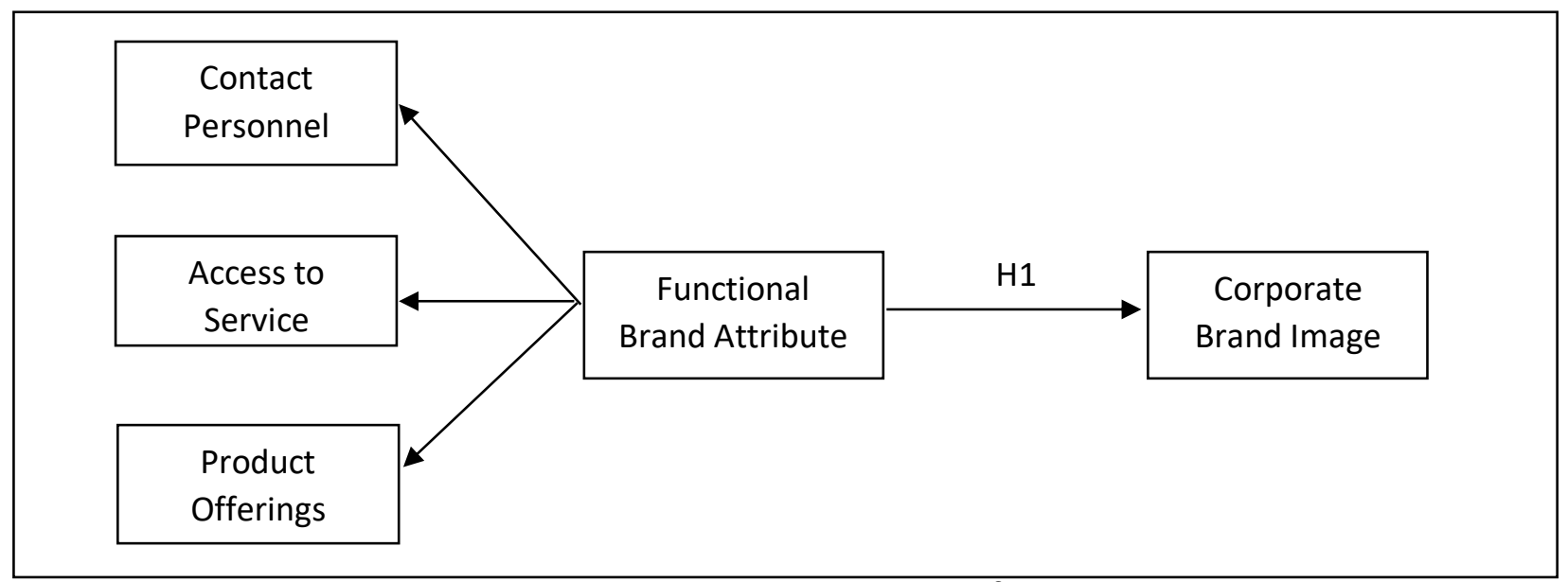

Figure 1.0 Proposed conceptual framework 
INTERNATIONAL JOURNAL OF ACADEMIC RESEARCH IN BUSINESS AND SOCIAL SCIENCES

Vol. 8, No. 12, Dec, 2018, E-ISSN: 2222-6990 @ 2018 HRMARS

\section{Research Methodology}

A quantitative research technique using survey questionnaire will be used in this study. Population of the study includes customers of Islamic banking services in Malaysia. A purposive sampling technique will be adopted to select respondents of the study. In order to test the hypothesis, a Partial Least Square analysis will be conducted using PLS-SEM software. The measurement model will be analysed first in order to ensure its validity and reliability before the structural model is tested to find the answer for the hypothesis.

\section{Conclusion}

A conceptual model has been proposed to identify the relationship between the functional brand attributes and the overall corporate brand image of Islamic banking institutions. The study contributes to the body of knowledge by determining the role of functional attributes towards image in the context of an organisation carrying an Islamic identity. Other than that, it is hoped that findings of the study would provide guidelines for the Islamic banking industry in Malaysia, especially in managing their corporate identity so that the image seen by consumers will be favourable. Future studies could consider to include other attributes of a brand such as the emotional and spiritual brand attributes to understand how they interact in influencing image.

\section{References}

Aaker, D. A. (1991). Managing brand equity: Capitalizing on a value of a brand name. New York: The Free Press.

Ahmad, K., Rustam, G. A., \& Dent, M. M. (2011). Brand preference in Islamic banking. Journal of Islamic Marketing, 2(1), 74-82.

Ahmad, M. (2007). The Attitude of Bank Customers and Professional Bankers towards Islamic and Conventional Banks in Bangladesh. In Islamic Banking and Finance: Fundamentals and Contemporary Issues (pp. 169-196). Jeddah: Islamic Development Bank. Retrieved from http://www.ses.ac.ir/files/takmili/islamic_econ./islamic_banking/222.pdf\#page=203

Al-Tamimi, H. A. H., Lafi, A. S., \& Uddin, M. H. (2009). Bank Image in the UAE: Comparing Islamic and Conventional Banks. Journal of Financial Services Marketing, 14(3), 232-244.

Andreassen, T. W., \& Lindestad, B. (1998). Customer loyalty and complex services: The impact of corporate image on quality, customer satisfaction and loyalty for customers with varying degrees of service expertise. International Journal of Service Industry Management, 9(1), 7-23.

Anisimova, T. (2014). Benchmarking desired corporate brand image in relation to stakeholders: a managerial perspective. Qualitative Market Research: An International Journal, 17(4), 441-463.

Aranda, E., Gómez, M., \& Molina, A. (2015). Consumers' brand images of wines: Differences between two leading Spanish denominations of origin. British Food Journal, 117(8), 2057-2077.

Arpan, L. M., Raney, A. A., \& Zivnuska, S. (2003). A cognitive approach to understanding university image. Corporate Communications: An International Journal, 8(2), 97-113.

Ashraf, S., Robson, J., \& Sekhon, Y. (2015). Consumer trust and confidence in the compliance of Islamic banks. Journal Of Financial Services Marketing, 20(2), 133-144.

Awan, H. M., \& Bukhari, K. S. (2011). Customer's criteria for selecting an Islamic bank: evidence from Pakistan. Journal of Islamic Marketing, 2(1), 14-27. 
INTERNATIONAL JOURNAL OF ACADEMIC RESEARCH IN BUSINESS AND SOCIAL SCIENCES

Vol. 8, No. 12, Dec, 2018, E-ISSN: 2222-6990 @ 2018 HRMARS

Barich, H., \& Kotler, P. (1991). A framework for marketing image management. Sloan Management Review, 32(2), 94-104.

Bhat, S., \& Reddy, S. K. (1998). Symbolic and functional positioning of brands. Journal of Consumer Marketing, 15(1), 32-43.

Biel, A. L. (1993). Converting image into equity. In Brand Equity \& Advertising: Advertising's Role in Building Strong Brands (pp. 67-82). New Jersey: Lawrence Erlbaum Associates. Retrieved from https://books.google.com.my/books?hl=en\&lr=\&id=mRbhAQAAQBAJ\&oi=fnd\&pg=PA67\&dq=c onverting+image+into+equity\&ots=WY_z8sd62v\&sig=JF528RZuz32jYecqn-

14TZeP4zQ\&redir_esc=y\#v=onepage \& $q=$ converting image into equity $\& f=f a l s e$

Bravo, R., Montaner, T., \& Pina, J. M. (2010). Corporate brand image in retail banking: development and validation of a scale. The Service Industries Journal, 30(8), 1199-1218.

Chen, C.-C., Chen, P.-K., \& Huang, C.-E. (2012). Brands and consumer behavior. Social Behavior \& Personality: An International Journal, 40(1), 105-114.

Chong, B. S., \& Liu, M. H. (2009). Islamic banking: Interest-free or interest-based? Pacific Basin Finance Journal, 17(1), 125-144.

Chung, K., Yu, J.-E., Kim, W., \& Shin, J.-I. (2016). The antecedent and consequences of brand image in a low-priced cosmetic brand of South Korea: the moderating effect of gender. International Journal of $U$ - and e-Service, Science and Technology, 9(2), 175-184.

Da Silva, R. V., \& Syed Alwi, S. F. (2006). Cognitive, affective attributes and conative, behavioural responses in retail corporate branding. Journal of Product \& Brand Management, 15(5), 293305.

Da Silva, R. V., \& Syed Alwi, S. F. (2008). Online corporate brand images and consumer loyalty. Brand Management, 16(3), 119-144.

Devlin, J. F., Ennew, C. T., \& Mirza, M. (1995). Organizational Positioning in Retail Financial Services. Journal of Marketing Management, 11(1-3), 119-132.

DiMingo, E. (1987). The fine art of positioning. The Journal of Business Strategy, 9(2), 34-38.

Dowling, G. R. (1986). Managing your corporate images. Industrial Marketing Management, 15, 109115.

Durna, U., Dedeoglu, B. B., \& Balikçioglu, S. (2015). The role of servicescape and image perceptions of customers on behavioral intentions in the hotel industry. International Journal of Contemporary Hospitality Management, 27(7), 1728-1748.

Fatt, J. P. T., Wei, M., Yuen, S., \& Suan, W. (2000). Enhancing Corporate Image in Organisations. Management Research News, 23(5/6), 28-54.

Fetscherin, M., \& Usunier, J.-C. (2012). Corporate branding: An interdisciplinary literature review. European Journal of Marketing, 46(5), 733-753.

Gray, E. R., \& Balmer, J. M. T. (1998). Managing corporate image and corporate reputation. Long Range Planning, 31(5), 695-702.

Haedrich, G. (1993). Images and strategic corporate and marketing planning. Journal of Public Relations Research, 5(2), 83-93.

Hosany, S., Ekinci, Y., \& Uysal, M. (2006). Destination image and destination personality: An application of branding theories to tourism places. Journal of Business Research, 59(5), 638-642.

Hsieh, M., Pan, S., \& Setono, R. (2004). Product-, corporate-, and country-image dimensions and 
INTERNATIONAL JOURNAL OF ACADEMIC RESEARCH IN BUSINESS AND SOCIAL SCIENCES

Vol. 8, No. 12, Dec, 2018, E-ISSN: 2222-6990 @ 2018 HRMARS

purchase behavior: a multicountry analysis. Journal of the Academy of Marketing Science, 32(3), 251-270.

IFSB. (2016). Islamic Financial Services Industry: Stability Report 2016. Islamic Financial Services Board (Vol. 1).

Islam, J. U., \& Rahman, Z. (2017). Awareness and willingness towards Islamic banking among Muslims : an Indian perspective. International Journal of Islamic and Middle Eastern Finance and Management, 10(1).

Jalilvand, M. R., \& Samiei, N. (2012). The effect of electronic word of mouth on brand image and purchase intention. Marketing Intelligence \& Planning, 30(4), 460-476.

Keller, K. L. (1993). Conceptualizing, measuring, and managing customer-based brand equity. Journal of Marketing, 57(1), 1.

Kennedy, S. H. (1977). Nurturing corporate images. European Journal of Marketing (Vol. 11).

Khan, F. (2010). How "Islamic" is Islamic Banking? Journal of Economic Behavior and Organization, 76(3), 805-820.

Kim, J. H., \& Hyun, Y. J. (2011). A model to investigate the influence of marketing-mix efforts and corporate image on brand equity in the IT software sector. Industrial Marketing Management, 40(3), 424-438.

Langrehr, F. W. (1985). Consumer images of two types of competing financial service retailers. Journal of the Academy of Marketing Science, 13(3), 248-264.

Leblanc, G., \& Nguyen, N. (1996). Cues used by customers evaluating corporate image in service firms: An empirical study in financial institutions. International Journal of Service Industry Management, 7(2), 44-56.

Martenson, R. (2007). Corporate brand image, satisfaction and store loyalty: A study of the store as a brand, store brands and manufacturer brands. International Journal of Retail \& Distribution Management, 35(7), 544-555.

Martin, H. S., \& Bosque, I. A. R. del. (2008). Exploring the cognitive-affective nature of destination image and the role of psychological factors in its formation. Tourism Management, 29, 263-277.

Martineau, P. (1958). Sharper focus for the corporate image. Harvard Business Review, 36(6), 49-58.

Maulan, S., Omar, N. A., \& Ahmad, M. (2016). Measuring Halal Brand Association (HalBA) for Islamic Banks. Journal of Islamic Marketing, 7(3), 331-354.

Michel, G., \& Rieunier, S. (2012). Nonprofit brand image and typicality influences on charitable giving. Journal of Business Research, 65(5), 701-707.

Minkiewicz, J., Evans, J., Bridson, K., \& Mavondo, F. (2011). Corporate image in the leisure services sector. Journal of Services Marketing, 25(3), 190-201.

Nguyen, N., \& Leblanc, G. (2002). Contact personnel, physical environment and the perceived corporate image of intangible services by new clients. International Journal of Service Industry Management, 13(3), 242-262.

O'Cass, A., \& Grace, D. (2003). An exploratory perspective of service brand associations. Journal of Services Marketing, 17(5), 452-475.

Osman, I., Ali, H., Mokhtar, I., Setapa, F., \& Abd Malek, A. B. (2016). Corporate image and brand identification of Islamic Banks: the perspective of customers. In Proceedings of the 1st AAGBS International Conference on Business Management 2014 (AiCoBM 2014) (pp. 297-308). Springer 
INTERNATIONAL JOURNAL OF ACADEMIC RESEARCH IN BUSINESS AND SOCIAL SCIENCES

Vol. 8, No. 12, Dec, 2018, E-ISSN: 2222-6990 @ 2018 HRMARS

Singapore.

Osman, I., Syed Alwi, S. F., Mokhtar, I., Ali, H., Setapa, F., Rahim, A. R. A., \& Muda, R. (2015). Integrating institutional theory in determining corporate image of Islamic banks. In Procedia Social and Behavioral Sciences (Vol. 211, pp. 560-567). Elsevier B.V.

Padgett, D., \& Allen, D. (1997). Communicating Experiences: A Narrative Approach to Creating Service Brand Image. Journal of Advertising, 26(4), 49-62.

Palacio, A. B., Meneses, G. D., \& Pérez, P. J. P. (2002). The configuration of the university image and its relationship with the satisfaction of students. Journal of Educational Administration, 40(5), 486-505.

Park, W., Jaworski, B. J., \& Maclnnis, D. J. (1986). Strategic brand concept-image management. Journal of Marketing.

Sallam, M. A. (2016). An Investigation of Corporate Image Effect on WOM: The Role of Customer Satisfaction and Trust. International Journal of Business Administration, 7(3), 27-35.

Sondoh Jr, S. L., Wan Omar, M., Abdul Wahid, N., Ismail, I., \& Harun, A. (2007). The effect of brand image on overall satisfaction and loyalty intention in the context of color cosmetic. Asian Academy of Management Journal, 12(1), 83-107.

Stern, B., Zinkhan, G. M., \& Jaju, A. (2001). Marketing images: construct definition, measurement issues, and theory development. Marketing Theory, 1(2), 201-224.

Syed Alwi, S. F., \& Kitchen, P. J. (2014). Projecting corporate brand image and behavioral response in business schools: Cognitive or affective brand attributes? Journal of Business Research, 67(11), 2324-2336.

Temporal, P. (2011). Islamic Branding and Marketing. Singapore: John Wiley \& Sons.

Van Rekom, J., Jacobs, G., \& Verlegh, P. W. J. (2006). Measuring and managing the essence of a brand personality. Marketing Letters, 17(3), 181-192.

Winchester, M., \& Fletcher, M. (2000). Calibrating Your Brand Image Measurement Technique by Utilising Empirical Generalisations. Brand Management, 8(2), 99-110.

Yeo, R. K., \& Youssef, M. A. (2010). Communicating corporate image into existence: the case of the Saudi banking industry. Corporate Communication An International Journal, Vol.15.No., 263280. 